\title{
PENGEMBANGAN BAHAN AJAR OPTIK GEOMETRI BERBASIS INKUIRI UNTUK MAHASISWA PENDIDIKAN FISIKA
}

\author{
Rahmah Hayati Nasution ${ }^{1}$, Abdul Muin Sibuea ${ }^{2}$, R.Mursid $^{3}$ \\ ${ }^{I}$ STKIP Tapanuli Selatan Padangsidimpuan, Sumatera Utara \\ ${ }^{2,3}$ FT universitas Negeri Medan, Sumatera Utara \\ Rahma_zidan@yahoo.com
}

\begin{abstract}
Abstrak: Penelitian ini bertujuan untuk menghasilkan bahan ajar modul optik geometri berbasis inkuiri untuk mahasiswa pendidikan fisika STKIP Tapanuli selatan Padangsidimpuan, dan untuk mengetahui kelayakan dan keefektifan bahan ajar optik geometri berbasis inkuiri untuk mahasiswa pendidikan fisika STKIP Tapanuli Selatan Padangsidimpuan. Jenis penelitian yang digunakan adalah penelitian pengembangan dengan menggunakan pengembangan model Borg and Gall dan pengembangan modul merujuk pada Dick and Carey. Hasil penelitian ini menunjukkan: (1) Uji ahli materi pelajaran optik geometri berada pada kriteria sangat baik dan layak digunakan (89,06\%), (2) Uji ahli media pembelajaran berada pada kriteria sangat baik dan layak digunakan (92,18\%), (3) Penilaian dosen fisika berada pada kriteria sangat baik (89,50\%), (4) Uji coba perorangan berada pada kriteria sangat baik (82,95\%), (5) Uji coba kelompok kecil berada pada kriteria sangat baik (85,98\%), (6) Uji coba lapangan berada pada kriteria sangat baik (86,00\%), (7) Bahan ajar optik geometri berbasis inkuiri untuk mahasiswa pendidikan fisika STKIP "Tapanuli Selatan" Padangsidimpuan sangat efektif digunakan. Hal ini terlihat dari hasil tes kemampuan mahasiswa setelah perkuliahan dengan menggunakan bahan ajar modul ini tuntas karena $\geq 80 \%$ dari subjek uji coba memenuhi ketuntasan belajar dan adanya aktivitas yang positif dari mahasiswa.
\end{abstract}

Kata Kunci: Pengembangan, Bahan Ajar Optik Geometri Berbasis Inkuiri.

\begin{abstract}
This study aims to produce inquiry-based geometric optical module teaching materials for the STKIP Tapanuli South Padangsidimpuan physics education students, and to determine the feasibility and effectiveness of inquiry-based geometric optical teaching materials for STKIP physics education students in South Tapanuli Padangsidimpuan. The type of research used is development research using the development of the Borg and Gall model and module development referring to Dick and Carey. The results of this study indicate: (1) Test of expert geometry optical subject matter is in the criteria of very good and feasible to use (89.06\%), (2) Test of expert media learning is on the criteria of very good and feasible use (92.18\%) , (3) Physics lecturers' assessment is in very good criteria (89.50\%), (4) Individual trials are in very good criteria (82.95\%), (5) Small group trials are in very good criteria (85.98\%), (6) Field trials are in very good criteria (86.00\%), (7) Inquiry based geometry optical teaching materials for STKIP physics education students "South Tapanuli" Padangsidimpuan are very effective to use. This can be seen from the results of the student's ability test after the lecture by using this module teaching material thoroughly because $80 \%$ of the test subjects met the learning completeness and the positive activity of the students.
\end{abstract}

Keywords: Development, Inquiry-Based Geometry Optics Learning Materials.

\section{PENDAHULUAN}

Gelombang adalah mata kuliah wajib yang harus diikuti oleh mahasiswa Program Studi Pendidikan Fisika Sekolah Tinggi Keguruan dan Ilmu Pendidikan (STKIP) Tapanuli Selatan Padangsidimpuan. Tujuan mata kuliah Gelombang berdasarkan silabus Program Studi Pendidikan Fisika STKIP Tapanuli Selatan Padangsidimpuan adalah agar mahasiswa memiliki kemampuan untuk menyatakan deskripsi gelombang dalam berbagai medium, serta sifat-sifat umum 
gelombang dan penerapannya pada gelombang permukaan air, gelombang bunyi, serta gelombang elektromagnetik. Tujuan mata kuliah gelombang dalam tiga tahun terakhir ini dapat dikatakan belum tercapai.

Berdasarkan kesulitan mahasiswa dalam menemukan konsep gelombang rata-rata 90\% dikarenakan bahan ajar yang kurang efektif, maka bahan ajar adalah salah satu bagian dari perkuliahan yang sangat tepat dan dapat memberikan keuntungan kepada mahasiswa. Menurut Setiawan (2007: 116), bahan ajar yang disusun dengan baik dapat memberikan banyak keuntungan bagi mahasiswa antara lain: membantu mahasiswa belajar tanpa harus ada dosen, mahasiswa dapat belajar kapan dan dimana saja, mahasiswa dapat belajar dengan kecepatan sendiri, mahasiswa dapat belajar menurut urutannya sendiri, dan meningkatkan potensi mahasiswa agar menjadi mahasiwa mandiri.

Untuk mengatasi masalah tersebut perlu dicarikan bahan ajar gelombang yang sesuai dan dapat menyelesaikan permasalah di atas. Bahan ajar yang sesuai dengan kondisi ini adalah bahan ajar gelombang berbasis inkuiri. Menurut Sanjaya (2006:196), Pembelajaran yang menggunakan model inkuiri adalah pembelajaran yang menekankan pada proses berpikir secara kritis dan analitis untuk mencari dan menemukan sendiri jawaban dari suatu masalah yang dipertanyakan. Melalui pembelajaran yang dilakukan dengan model inkuiri diharapkan mahasiswa dapat menemukan sendiri konsep-konsep dan prinsip fisika sehingga ilmu pengetahuan yang diperoleh bertahan lebih lama. Berdasarkan uraian di atas maka dalam penelitian ini perlu dikembangkan bahan ajar Optik Geometri Berbasis Inkuiri untuk mahasiswa pendidikan fisika STKIP Tapanuli Selatan Padangsidimpuan.

Purwanto (2007:84) menyatakan bahawa belajar adalah setiap perubahan relatif menetap dalam tingkah laku yang terjadi sebagai situasi hasil dari latihan dan pengalaman. Selanjutnya menurut Gagne yang dikutip Mudjiono (2006:9) menyatakan bahwa belajar adalah kegiatan yang kompleks hasil belajar berupa kapabilitas setelah belajar orang memiliki keterampilan/pengetahuan, sikap, dan nilai.

Sagala (2008:160) mengemukakan bahwa pengalaman belajar yang disiapkan oleh pendidik akan memberi jaminaan kepada peserta didik bahwa mereka telah menempuh kurikulum yang dipersyaratkan dan memperoleh keterampilan sebagaimana kompetensi yang disiapkan. Syah (2010:148) menyatakan bahwa pada prinsipnya, pengungkapan hasil belajar ideal meliputi segenap ranah psikologis yang berubah sebagai akibat pengalaman dari proses belajar mahasiswa.

Kimble dan Garmezy (Ali, 2008:14) mengemukakan bahwa hasil belajar dapat diidentifikasi dari adanya kemampuan melakukan sesuatu secara permanen, dapat diulang-ulang dengan hasil yang sama.

Gelombang adalah getaran yang berpindah, tidak membawa materi bersamanya. Gelombang membawa energi dari satu tempat ke tempat lain. Energi diberikan ke gelombang air misalnya oleh batu yang dilemparkan ke air, atau oleh angin di laut lepas. Energi dibawa oleh gelombang ke pantai. Semua bentuk gelombang merambat membawa energi. Hampir semua benda bergetar benda bergetar mengirimkan gelombang, dengan demikian sumber gelombang adalah getaran (Giancoli, 2001: 381-382). Menurut Tipler (1998:471) gelombang merupakan perpindahan energi dan momentum dari satu titik di dalam ruang ke titik lain tanpa perpindahan materi. Priyambodo (2009:249) mengemukakan bahwa gelombang adalah gejala pemindahan usikan atau gangguan

$$
\text { Menurut Freedman }
$$
gelombang dapat terjadi apabila suatu sistem diganggu dari posisi kesetimbangannya dan bila gangguan itu dapat berjalan atau merambat dari satu daerah sistem itu ke daerah lainnya. Bueche (2006:154) menyatakan bahwa gelombang yang merambat adalah gangguan medium yang dapat berlanjut dengan sendirinya, yang bergerak dari satu titik ke titik lainnya, dengan membawa energi dan momentum.

Maxwell (1873) menyatakan bahwa sesungguhnya cahaya merupakan gelombang elektromagnetik karena kecepatan gelombang elektromagnetik sama dengan kecepatan cahaya, yaitu sebesar $3 \times 10^{8} \mathrm{~m} / \mathrm{s}$ (Young, 2004:495). Tipler (2001:420) menyatakan bahwa dalam gelombang elektromagnetik, vektor medan listrik dan magnetik keduanya saling tegak lurus dan tegak lurus terhadap arah rambatannya. Priyambodo (2009:275) menjelaskan bahwa cahaya merupakan gelombang sehingga memiliki sifat yang 
dimiliki oleh gelombang pada umumnya, termasuk dapat terjadi peristiwa interferensi dan difraksi

Optik geometri adalah studi tentang fenomena-fenomena dimana pendekatan sinar adalah sah (Tipler, 2001:479). Menurut Giancoli (2001:243) optik geometri adalah suatu penjelasan tentang model berkas yang telah berhasil dalam mendeskripsikan banyak aspek cahaya seperti pemantulan, pembiasan, dan pembentukan bayangan oleh cermin dan lensa.

Bahan ajar adalah segala bentuk bahan yang digunakan untuk membantu dosen atau instruktur dalam melaksanakan kegiatan belajar mengajar di kelas. Bahan ajar memiliki posisi amat penting dalam pembelajaran, yakni sebagai representasi (wakil) dari penjelasan dosen di depan kelas. Keterangan-keterangan dosen, uraian-uraian yang harus disampaikan dosen, dan informasi yang harus disajikan dosen dihimpun di dalam bahan ajar. Dengan demikian, dosen juga akan dapat mengurangi kegiatannya menjelaskan pelajaran, memiliki banyak waktu untuk membimbing mahasiswa dalam belajar atau membelajarkan mahasiswa (Zulkarnaini, 2009:1).

Bahan ajar adalah bahan-bahan atau materi pelajaran yang disusun secara sistematis, yang digunakan dosen dan mahasiswa dalam proses pembelajaran (Belawati, 2003:1.12). Menurut Belawati (2003:1.13) bahan ajar dikelompokan ke dalam tiga kelompok besar, yaitu jenis bahan ajar cetak, noncetak, dan bahan ajar display. Bahan ajar cetak adalah sejumlah bahan yang digunakan dalam kertas, yang dapat berfungsi untuk keperluan pembelajaran atau penyampaian informasi (Kemp dan Dayton, 1985 dalam Belawati, 2003:1.14).

Menurut Tarigan dan Tarigan (1986:20) kriteria telaah bahan ajar meliputi: (1) kurikulum yang berlaku; (2) karakteristik mata pelajaran (ilmu yang relevan); (3) hubungan antara kurikulum, mata pelajaran, dan bahan ajar; (4) dasar-dasar pengembangan bahan ajar; (5) kualitas bahan ajar; (6) prinsipprinsip pengembangan buku kerja; dan (7) penyeleksian buku kerja. Penilaian bahan ajar menurut Supriadi (2001:9) meliputi: mutu isi buku, kesesuaian dengan kurikulum, bahasa yang digunakan termasuk penyajian dan keterbacaannya, grafika, dan keamanan buku.

Model Dick \& Carey (2005:9) adalah salah satu contoh model pengembangan yang berorientasi pada hasil, karena penerapan konsep-konsep dan prinsip-prinsip perancangannya akan menghasilkan bahan belajar mandiri. Menurut Dick \& Carey seperti ditunjukkan desain pengembangan pembelajaran dapat dilakukan dengan menggunakan tahap-tahap sebagai berikut: (1) Identifikasi tujuan pembelajaran; (2) Melakukan analisis pembelajaran; (3) Identifikasi perilaku dan karakteristik awal; (4) Menulis tujuan kerja; (5) Mengembangkan tes acuan patokan; (6) Mengembangkan strategi pembelajaran; (7) Mengembangkan dan memilih materi pembelajaran; (8) Mendesain dan melaksanakan evaluasi formatif; (9) Merevisi kegiatan pembelajaran; (10) Mendesain dan melaksanakan evaluasi sumatif.

Menurut Heinich (1996: 48) tahap perencanaan awal dimulai dengan adanya ide atau gagasan untuk menghasilkan suatu produk. Mukminan (2004:38) menyatakan bahwa menganalisis berarti merinci suatu standar kompetensi menjadi kompetensi dasar setelah mendapat rincian standar kompetensi, tugas berikutnya adalah mengurutkan kompetensi dasar tersebut. Dick \& Carey (2005:61) menjelaskan bahwa program pembelajaran perlu disesuaikan dengan kebutuhan siswa karena itu harus ditentukan dengan pasti karakteristik pengetahuan dan keterampilan awal peserta didik sebelum mengikuti program pembelajaran agar dapat mengikuti program pembelajaran tadi dengan baik. Pada pembelajaran gelombang berbasis inkuiri peserta didik dituntut dapat memahami materi tersebut.

Menurut Sadiman (2006:182) ada dua macam evaluasi media, yaitu evaluasi formatif dan evaluasi sumatif. Sadiman (2006:182-186) menyatakan ada tiga tahap evaluasi formatif yaitu: (1) Evaluasi satu lawan satu (one to one). (2) Evaluasi kelompok kecil (small group evaluation). (3) Evaluasi lapangan (field evaluation) adalah evaluasi tahap akhir. Menurut Kirkpatrick (Lee \& Owens, 2004: 224225) ada empat tingkat evaluasi dalam multimedia pembelajaran, yaitu: (1) Tingkat pertama (reaksi), menilai respon peserta terhadap aktivitas dalam bentuk kesan tentang relevansi dari aktivitas yang memungkinkan mereka untuk melakukan tugasnya, (2) Tingkat kedua (pengetahuan), menilai peningkatan pencapaian materi dan keterampilan yang diinginkan dari aktivitas yang dilakukan, (3) Tingkat ketiga (performance), menilai perubahan sikap atau tingkah laku sebagai 
akibat dari pemanfaatan pengetahuan dan keterampilan dari aktivitas yang ditransfer ke dalam pekerjaan dalam periode waktu tertentu, (4) Tingkat keempat (pengaruh), menilai pengaruh business dalam bentuk pengembalian (return on investment/ROI) dari aktivits yang dilakukan.

Evaluasi adalah upaya sistematikal untuk melihat efektivitas dan efisiensi program. Menurut Widoyoko (2009:76) produk akhir kegiatan evaluasi adalah keputusan tentang efektivitas dan efisiensi suatu program. Model pengembangan Borg dan Gall (1983:772) memuat panduan sistematika langkah-langkah yang dilakukan produk yang dirancang mempunyai standar kelayakan.

Borg \& Gall (1983:775) menyatakan bahwa prosedur penelitian pengembangan pada dasarnya terdiri dari dua tujuan utama, yaitu: (a) mengembangkan produk, dan (b) menguji keefektifan produk dalam mencapai tujuan. Tujuan pertama disebut sebagai fungsi pengembang sedangkan tujuan kedua disebut sebagai validasi. Dengan demikian, konsep penelitian pengembangan lebih tepat diartikan sebagai upaya pengembangan yang sekaligus disertai dengan upaya validasinya. Borg dan Gall (1983:775) mengajukan serangkaian tahap yang harus ditempuh dalam pendekatan ini mencakup 10 langkah umum.

Tindakan utama pembelajaran dapat diaplikasikan dalam proses pengembangan bahan ajar (Trianto, 2005:10). Selanjutnya Tomlinson (1998:98) memaparkan tahap-tahap pengembangan bahan ajar, yakni: (1) identifikasi kebutuhan dosen dan mahasiswa, (2) penentuan kegiatan eksplorasi kebutuhan materi, (3) realisasi kontekstual dengan mengajukan gagasan yang sesuai dengan pemilihan teks dan konteks bahan ajar, (4) realisasi pedagogis melalui tugas dan latihan, (5) produksi bahan ajar, ((6) penggunaan bahan ajar oleh mahasiswa, dan (7) evaluasi bahan ajar. Kemudian Trianto (2005:10) mengajukan rancangan pengembangan bahan ajar, meliputi: (1) pengembangan tujuan, (2) pengembangan silabus, (3) pengorganisasian bahan ajar kedalam unit-unit pembelajaran, pengembangan struktur per unit, dan (5) pengurutan unit.

Menurut Tomlinson pengembangan bahan ajar adalah apa yang dilakukan penulis, dosen, mahasiswa untuk memberikan sumber masukan berbagai pengalaman yang dirancang untuk meningkatkan belajar gelombang. Menurut Heinich (1996: 48) tahap perencanaan awal dimulai dengan adanya ide atau gagasan untuk menghasilkan suatu produk. Mukminan (2004:38) menyatakan bahwa menganalisis berarti merinci suatu standar kompetensi menjadi kompetensi dasar setelah mendapat rincian standar kompetensi, tugas berikutnya adalah mengurutkan kompetensi dasar tersebut.

Menurut Lufri (2008:27), pendekatan inkuiri merupakan pendekatan pembelajaran yang mengarahkan mahasiswa untuk menemukan pengetahuan, ide, dan informasi melalui usaha sendiri. Menurut Sanjaya (2006:196-197), ciri-ciri pembelajaran inkuiri antara lain: (1) model inkuiri menekankan pada aktivitas mahasiswa secara maksimal untuk mencari dan menemukan, artinya inkuiri menempatkan mahasiswa sebagai subjek belajar, (2) seluruh aktivitas yang dilakukan mahasiswa diarahkan untuk mencari dan menemukan jawaban sendiri dari suatu yang dipertanyakan, (3) tujuan dari penggunaan model inkuiri adalah mengembangkan kemampuan berpikir secara sistematis, logis, dan kritis.

Menurut Sanjaya (2006:198), penggunaan inkuiri harus memperhatikan beberapa prinsip, yaitu berorientasi pada pengembangan intelektual (pengembangan kemampuan berfikir), prinsip interaksi (interaksi antar mahasiswa maupun interaksi antara mahasiswa dengan dosen bahkan antara mahasiswa dengan lingkungan), prinsip bertanya (dosen sebagai penanya), prinsip belajar untuk berfikir (learning how to think), prinsip keterbukaan (menyediakan ruang untuk memberikan kesempatan kepada mahasiswa mengembangkan hipotesis dan secara terbuka membuktikan kebenaran hipotesis yang diajukan).

$$
\text { Menurut Hacket }
$$

mengemukakan bahwa Inkuiri digunakan dalam dua terminologi yaitu sebagai pendekatan pembelajaran oleh guru dan sebagai materi pelajaran yang harus dipahami dan mampu dilakukan oleh siswa. Wina Sanjaya (2008:303) mengemukakan bahwa metode inkuiri adalah rangkaian kegiatan pembelajaran yang menekankan pada proses berpikir secara kritis dan analitis untuk mencari suatu fakta. SedangkanHamdani (2011:182) mengemukakan bahwa metode Inkuri merupakan suatu teknik atau cara yang digunakan guru untuk mengajar di depan kelas. 
Berdasarkan latar belakang dan mengingat identifikasi masalah serta batasan masalah, maka rumusan masalah dalam penelitian ini adalah: (1) Apakah bahan ajar Optik Geometri berbasis inkuiri yang dihasilkan memenuhi syarat dan layak sebagai media pembelajaran yang baik bagi mahasiswa Pendidikan Fisika STKIP Tapanuli selatan Padangsidimpuan?. (2) Apakah Bahan Ajar Optik Geometri Berbasis Inkuiri efektif digunakan untuk mahasiswa pendidikan fisika STKIP Tapanuli Selatan Padangsidimpuan?.

Tujuan penelitian ini adalah: (1) Untuk mengetahui apakah bahan ajar optik geometri berbasis inkuiri yang dihasilkan memenuhi syarat dan layak sebagai media pembelajaran yang baik bagi mahasiswa fisika STKIP Tapanuli selatan Padangsidimpuan. (2) Untuk mengetahui keefektifan bahan ajar optik geometri berbasis inkuiri yang dihasilkan bagi mahasiswa pendidikan fisika STKIP Tapanuli selatan Padangsidimpuan.

\section{METODE}

Penelitian ini dilaksanakan di STKIP Tapanuli selatan Padangsidimpuan, pada mahasiswa Pendidikan Fisika semester VI tahun ajaran 2014/2015 pada mata kuliah gelombang materi pokok Optik geometrik. Waktu penelitian ini dilaksanakan pada bulan Februari 2015 dan selesai pada bulan Agustus 2015 yang disesuaikan dengan silabus perkuliahan. Populasi adalah keseluruhan objek penelitian. Hal ini sejalan dengan pendapat Usman (2009:42) Populasi adalah semua nilai baik hasil perhitungan maupun pengukuran, baik kuantitatif maupun kualitatif, daripada karakteristik tertentu mengenai sekelompok objek yang lengkap dan jelas. Populasi penelitian ini adalah seluruh mahasiswa semester VI Pendidikan Fisika STKIP Tapanuli Selatan Padangsidimpuan yang berjumlah 22 orang yang terdiri dari 1 kelas.

\section{Menurut Arikunto}

(2006:134)

Mengingat jumlah populasi yang ada merupakan homogen dan jumlahnya lebih dari 100 orang maka untuk sekedar ancer-ancer, maka apabila subjeknya kurang dari 100, lebih baik diambil semua sehingga penelitiannya merupakan penelitian populasi, maka penulis

\section{HASIL PENELITIAN}

Berdasarkan hasil angket wawancara yang diperoleh dari 3 orang dosen dapat disimpulkan bahwa mahasiswa kurang mengambil sampel dari seluruh populasi yaitu sebanyak 1 kelas sehingga jumlah sampel penelitian di semester VI mahasiswa pendidikan fisika STKIP Tapanuli Selatan Padangsidimpuan sebanyak 22 orang.

Penelitian pengembangan ini merujuk pada langkah-langkah penelitian pengembangan model Borg and Gall, pengembangan modul merujuk pada Dick and Carey. Langkah-langkah yang dilakukan dalam pengembangan Borg and Gall) adalah: (1) tahap analisis kebutuhan, (2) tahap perancangan modul, dan (3) tahap uji coba (validasi). Sukmadinata (2006:186) menyederhanakan teori Borg and Gall menjadi 4 tahap: (1) studi pendahuluan, (2) perencanaan dan pengembangan model, (3) uji coba dan revisi, dan (4) validasi modul. Penelitian ini dilakukan dengan tahap tahap uji coba lebih luas yaitu dihasilkannya produk modul dan dilanjutkan sampai pengujian hasil (validasi media).

Setelah produk bahan ajar yang dihasilkan divalidasi oleh ahli media dan ahli materi, selanjutnya produk diuji cobakan kepada tiga orang dosen pendidikan fisika STKIP Tapanuli Selatan dan mahasiswa pendidikan fisika semester VI yang terbagi kepada tiga tahap uji coba yaitu (1) uji coba perorangan dilakukan oleh 3 mahasiswa pendidikan fisika semester VI yang memiliki tingkat pemahaman rendah, sedang, dan tinggi terhadap materi yang diajarkan. (2) uji coba kelompok kecil dilakukan oleh 9 mahasiswa pendidikan fisika semester VI yang memiliki tingkat pemahaman terhadap materi rendah sebanyak 3 orang, tingkat pemahaman sedang 3 orang, dan tingkat pemahaman tinggi 3 orang. Selanjutnya (3) uji coba lapangan yang dilakukan oleh seluruh mahasiswa pendidikan fisika semester VI yang berjumlah 22 orang.

Instrumen yang dipakai dalam penelitian ini ada yang merupakan hasil modifikasi dari instrumen dari pakar Modul yaitu: lembar validasi modul, lembar observasi, angket, pedoman wawancara, dan tes. Data yang diperoleh melalui berbagai instrumen dianalisis secara kuantitatif dan kulitatif, informasi yang diperoleh dari hasil observasi dan wawancara mengenai kelayakan modul dianalisis secara kualitatif.

memahami perkuliahan gelombang, karena belum adanya buku teks yang dapat digunakan untuk perkuliahan. Pelaksanaan perkuliahan belum dapat membuat mahasiswa aktif karena mahasiswa tidak memahami apa yang 
disampaikan oleh dosen. Dosen setuju jika materi perkuliahan diberikan dalam bentuk bahan ajar modul

Berdasarkan hasil perhitungan penilaian para dosen sebanyak 3 orang dosen terhadap bahan ajar optik geometri berbasis inkuiri, aspek-aspek dalam bahan ajar mendapatkan penilaian sangat baik. Maka dari hasil perhitungan diperoleh nilai rata-rata untuk seluruh aspek 3,58 dengan persentase skor total $89,50 \%$ yang termasuk dalam kategori "Sangat Baik". Rata-rata skor total dari hasil penilaian ahli media pembelajaran dapat dilihat pada diagram 1 berikut.

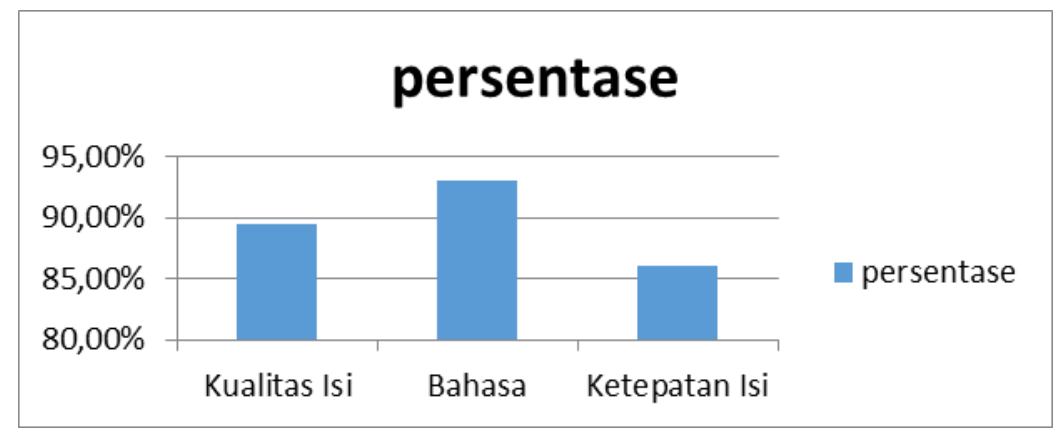

Gambar 1. Diagram jumlah skor rata-rata hasil penilaian dosen fisika

Menurut ahli materi kualitas bahan ajar modul pembelajaran secara keseluruhan aspek diperoleh nilai 3,562 dengan persentase skor 89,06\% yang termasuk dalam kategori "sangat baik" untuk digunakan. Secara diagram, jumlah skor rata-rata hasil penilaian terhadap bahan ajar optik geometri berbasis inkuiri oleh para ahli materi dapat dilihat pada diagram 2 berikut.

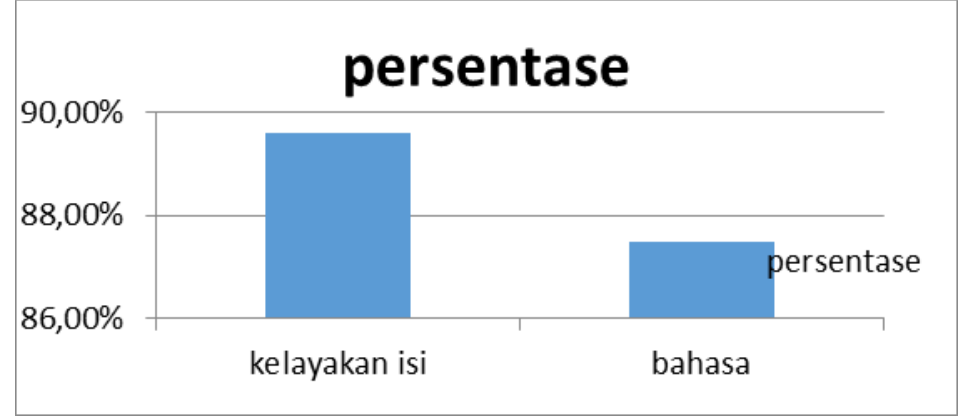

Gambar 2. Diagram jumlah skor rata-rata hasil penilaian ahli materi

Dari tabel 3 di atas, menurut ahli media pembelajaran kualitas bahan ajar optik geometri berbasis inkuiri dari beberapa aspek memiliki nilai skor rata-rata 3,6875 dengan persentase skor $92,18 \%$ maka bahan ajar modul layak untuk digunakan dan termasuk dalam kategori "sangat baik". Rata-rata skor total dari hasil penilaian ahli media pembelajaran dapat dilihat pada diagram 3 berikut.

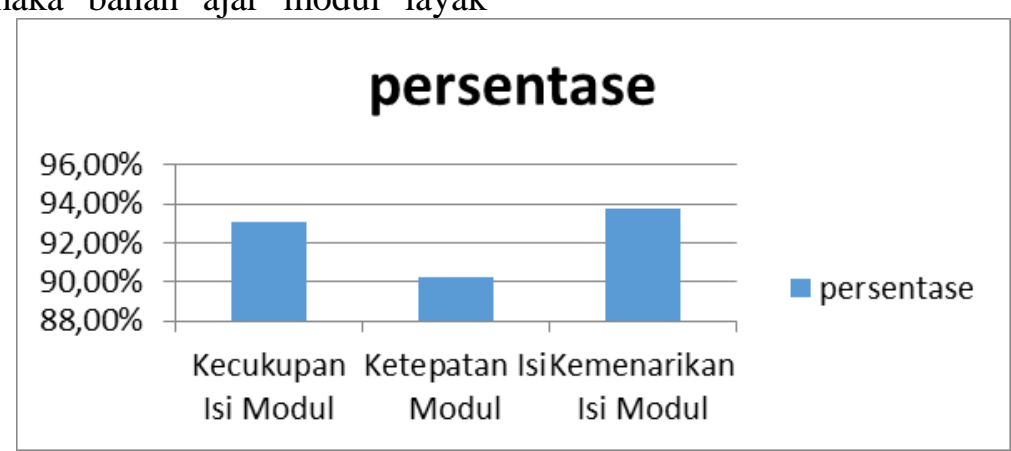

Gambar 3. Diagram jumlah skor rata-rata hasil penilaian ahli media

Tanggapan mahasiswa pada uji coba perorangan dijelaskan bahwa bahan ajar optik geometri berbasis inkuiri dari aspek-aspek secara keseluruhan termasuk dalam kriteria "sangat baik" dengan nilai rata-rata skor 3,333 dengan persentase skor $82,95 \%$. 
Persentase rata-rata penilaian bahan ajar optik geometri berbasis inkuiri pada uji coba perorangan yang dilakukan pada tiga orang mahasiswa Pendidikan Fisika STKIP Tapanuli Selatan Padangsidimpuan dapat dilihat pada diagram 4 berikut.

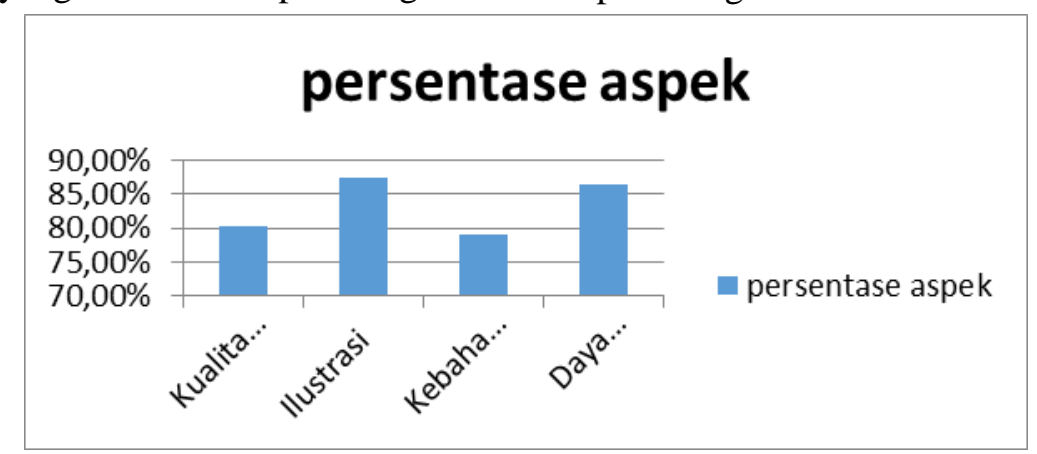

Gambar 4. Diagram persentase rata-rata hasil penilaian uji coba perorangan

Dari Tabel 5 diatas nilai persentase skor totalnya adalah $85,98 \%$, sehingga apabila dimasukkan kedalam kategori persentase maka validasi bahan ajar optik geometri berbasis inkuiri menurut ahli media pembelajaran dikategorikan dalam "sangat baik".
Persentase rata-rata dari hasil penilaian terhadap bahan ajar optik geometri berbasis inkuiri pada uji coba kelompok kecil dapat dilihat pada diagram 5 berikut.

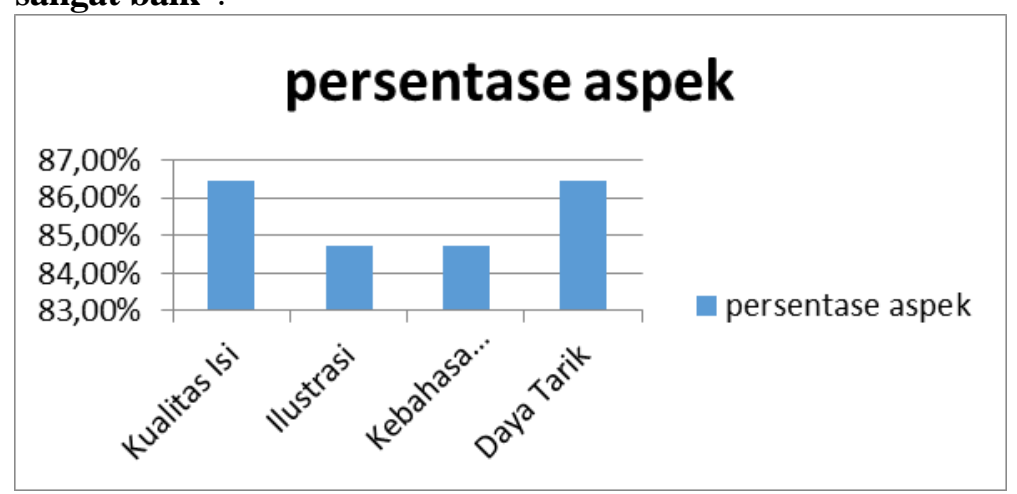

Gambar 5. Diagram persentase rata-rata hasil penilaian uji coba kelompok kecil

Tabel 1. Hasil Perhitungan Uji Coba Lapangan

\begin{tabular}{lccccc}
\hline \multirow{2}{*}{ Perhitungan } & \multicolumn{5}{c}{ Aspek } \\
\cline { 2 - 6 } & Kualitas Isi & Ilustrasi & Kebahasaan & Daya Tarik & Keseluruhan \\
\hline Jumlah Responden & 22 & 22 & 22 & 22 & 22 \\
Jumlah pernyataan & 8 & 2 & 4 & 8 & 22 \\
Jumlah skor & 597 & 150 & 301 & 617 & 1665 \\
Skor rata-rata & 3,392 & 3,409 & 3,420 & 3,505 & 3,440 \\
\hline Kategori & Sangat Setuju & Sangat Setuju & Sangat Setuju & Sangat Setuju & Sangat Setuju \\
\hline persentase skor & 84,8011 & 85,22 & 85,51 & 87,64 & 86 \\
\hline
\end{tabular}

Dari tabel 6 di atas terlihat bahwa persentasi skor total dari keseluruhan aspek adalah $86 \%$, sehingga apabila dimasukkan kedalam kategori persentase menurut Arikunto (1998:246) maka validasi bahan ajar modul menurut ahli media dikategorikan "sangat baik".

Persentase rata-rata dari hasil penilaian terhadap bahan ajar optik geometri berbasis inkuiri pada uji coba kelompok kecil dapat dilihat pada diagram 6 berikut. 


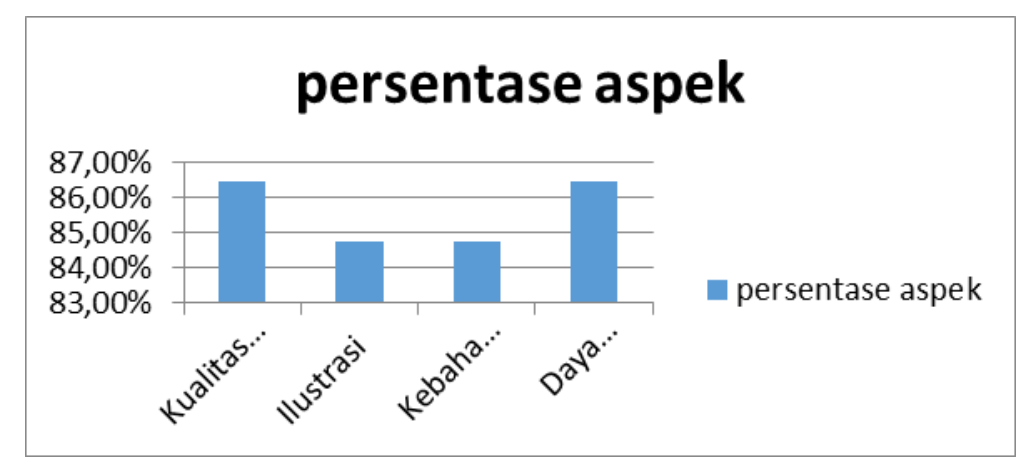

Gambar 6 Diagram persentase rata-rata hasil penilaian uji coba lapangan

Tabel 2. Persentase Skor Total Hasil Penilaian Validasi Ahli dan Uji Coba Bahan Ajar Optik Geometri Berbasis Inkuiri

\begin{tabular}{llcl}
\hline No & Responden & Persentase Rata-rata & Kriteria \\
\hline 1 & Ahli materi pembelajaran & $89,06 \%$ & Sangat baik \\
2 & Ahli media pembelajaran & $92,18 \%$ & Sangat baik \\
3 & Penilaian dosen fisika & $89,50 \%$ & Sangat baik \\
4 & Uji coba perorangan & $82,95 \%$ & Sangat baik \\
5 & Uji coba kelompok kecil & $85,98 \%$ & Sangat baik \\
6 & Uji coba lapangan & $86,00 \%$ & Sangat baik \\
\hline \multicolumn{2}{l}{ Rata-rata } & $87,61 \%$ & Sangat baik \\
\hline
\end{tabular}

Berdasarkan tabel 7 di atas diterangkan bahwa persentase skor total dari hasil penilaian velidasi ahli dan uji coba bahan ajar optik geometri berbasis inkuiri diperoleh nilai rata- rata $87,61 \%$ yang termasuk dalam kategori "sangat baik". Hal ini dapat dilihat pada diagram 7 berikut.

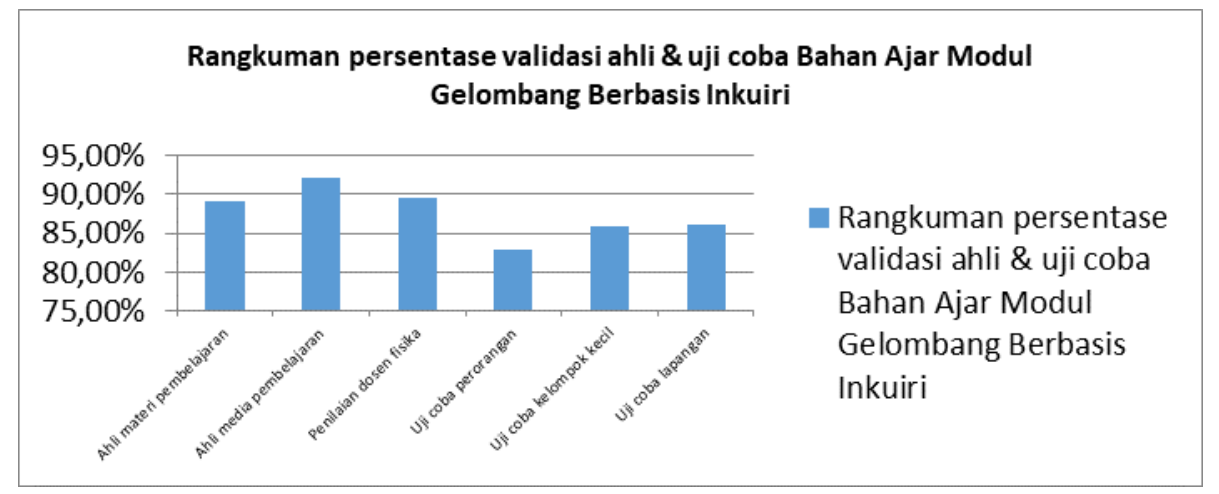

Gambar 7. Diagram rangkuman persentase skor total hasil penilaian validasi ahli dan uji coba modul pembelajaran

Tabel 3. Skor Mean, Median, Dan Modus Dari Pre-tes Hasil Belajar Optik Geometri Mahasiswa

\begin{tabular}{ccc}
\multicolumn{2}{c}{ Pendidikan Fisika STKIP Tapanuli Selatan } & Padangsidimpuan \\
\hline No & Keterangan & Skor \\
\hline 1 & Mean & 68,86 \\
2 & Median & 74,50 \\
3 & Modus & 79,20 \\
\hline
\end{tabular}

Nilai terendah 45 dan tertinggi 90 . Sedangkan nilai yang maksimal yang mungkin dicapai oleh mahasiswa adalah 0-100. Nilai tengah teoritisnya 50. Jika dibandingkan antara nilai rata-rata 68,86 dengan nilai tengah teoritis 50. Nilai rata-rata lebih besar dari pada nilai tengah teoritis. Jika nilai rata-rata lebih besar dari nilai tengah, maka hasil belajar optik geometri sudah sesuai dengan diharapkan, tetapi jika nilai rata-rata lebih rendah dari pada nilai tengah teoritis, maka hasil belajar optik geometri tidak sesuai dengan yang diharapkan. 
Tabel 4. Distribusi frekuensi Pre-tes Hasil Belajar Optik Geometri di STKIP Tapanuli Selatan Padangsidimpuan

\begin{tabular}{ccccc}
\hline No & Interval Nilai & Frekuensi & Presentase $(\%)$ & $\mathrm{F}_{\mathrm{kb}}$ \\
\hline 1 & $45-52$ & 3 & $14 \%$ & 3 \\
2 & $53-60$ & 4 & $18 \%$ & 7 \\
3 & $61-68$ & 3 & $14 \%$ & 10 \\
4 & $69-76$ & 4 & $18 \%$ & 14 \\
5 & $77-84$ & 6 & $27 \%$ & 20 \\
6 & $85-92$ & 2 & $9 \%$ & 22 \\
\hline & Jumlah & 22 & 100 & \\
\hline
\end{tabular}

Berdasarkan distribusi tabel 9 di atas nilai rata-rata berada pada interval kelas 61-68 dengan frekuensi 3 atau sebesar $14 \%$ dan nilai tertinggi dengan frekuensi 7 atau sebesar 54\%, dan nilai terendah dengan frekuensi 7 orang atau sebesar $32 \%$. Untuk lebih jelasnya data hasil penelitian yang telah diuraikan tersebut dapat digambarkan secara histogram 9 berikut.

\section{frekuensi}

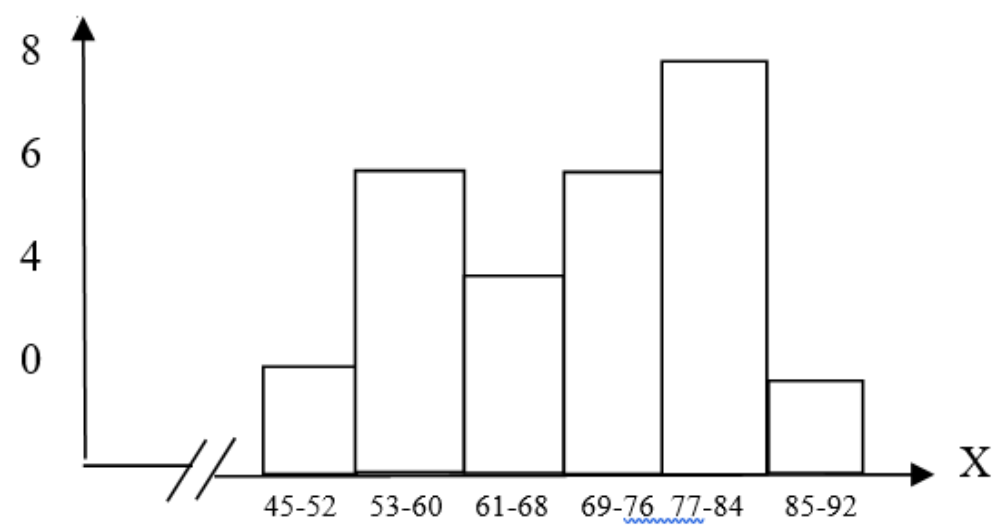

Gambar 9. Histogram Frekuensi Pre-tes Hasil Belajar Optik Geometri Sebelum Menggunakan Bahan Ajar Modul Gelombang Berbasis Inkuiri

Tabel 5. Skor Mean, Median, Dan Modus Dari Post-tes Hasil Belajar Optik Geometri mahasiswa Pendidikan Fisika Semester VI

\begin{tabular}{ccc}
\hline No & Keterangan & Skor \\
\hline 1 & Mean & 76,45 \\
2 & Median & 68,50 \\
3 & Modus & 73,00 \\
\hline
\end{tabular}

Nilai terendah 55 dan tertinggi 95 . Sedangkan nilai yang maksimal yang mungkin dicapai oleh mahasiswa adalah 0-100. Nilai tengah teoritisnya 50. Jika dibandingkan antara nilai rata-rata 76,45 dengan nilai tengah teoritis 50. Nilai rata-rata lebih besar dari pada nilai tengah teoritis. Jika nilai rata-rata lebih besar dari pada nilai tengah, maka hasil belajar optik geometri sudah sesuai dengan yang diharapkan, sedangkan jika nilai rata-rata lebih rendah dari pada nilai tengah teoritis, maka hasil belajar optik geometri tidak sesuai dengan yang diharapkan. 
Tabel 6. Distribusi Frekuensi Post-tes Hasil Belajar Optik Geometri di semester VI Mahasiswa Pendidikan Fisika STKIP Tapanuli Selatan Padangsidimpuan

\begin{tabular}{ccccc}
\hline No & Interval Nilai & Frekuensi & Presentase (\%) & $\mathbf{F}_{\mathbf{k b}}$ \\
\hline 1 & $55-61$ & 2 & $9 \%$ & 2 \\
2 & $62-68$ & 1 & $5 \%$ & 3 \\
3 & $69-75$ & 8 & $36 \%$ & 11 \\
4 & $76-82$ & 4 & $18 \%$ & 15 \\
5 & $83-89$ & 6 & $27 \%$ & 21 \\
6 & $90-96$ & 1 & $5 \%$ & 22 \\
\hline \multicolumn{7}{r}{} & Jumlah & 22 & 100 & \\
\hline
\end{tabular}

Berdasarkan tabel 11 di atas diketahui nilai rata-rata berada pada interval kelas $76-82$ dengan frekuensi 4 atau sebesar $18 \%$ dan nilai tertinggi dengan frekuensi 7 atau sebesar $32 \%$, dan nilai terendah dengan frekuensi 11 orang atau sebesar $50 \%$. Untuk lebih jelasnya data hasil penelitian yang telah diuraikan tersebut dapat digambarkan secara histogram 11 berikut.

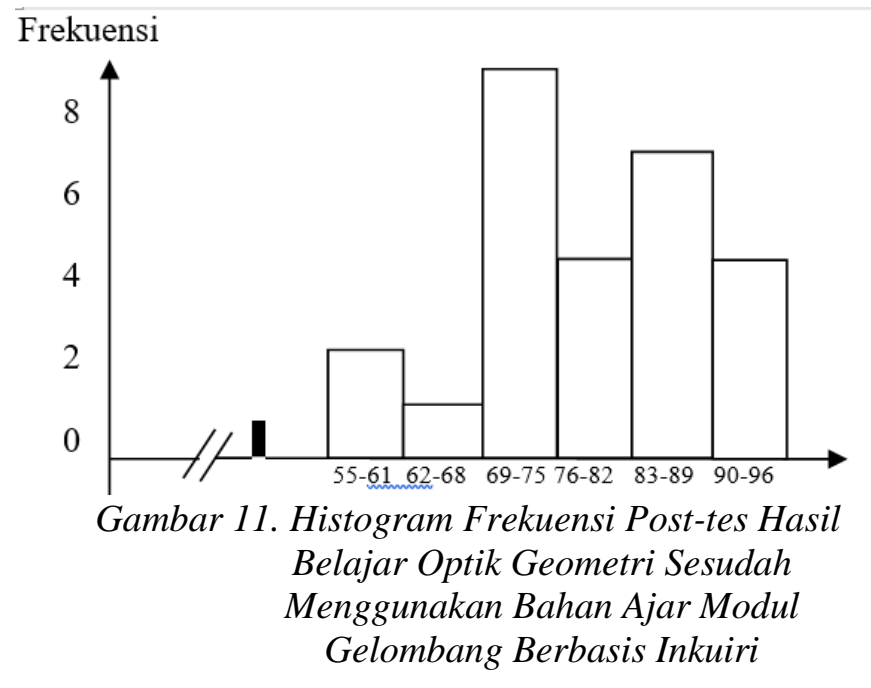

Tabel 7. Nilai Persentil Untuk Distribusi t

\begin{tabular}{cc}
\hline $\mathbf{N}$ & $\mathbf{t}_{\text {tabel }}$ \\
\hline 22 & 2,07 \\
20 & 2,09
\end{tabular}

Berdasarkan $t_{\text {tabel }} 2,09$ jika $t_{\text {hitung }} 5,6$ maka nilai $\mathrm{t}_{\text {hitung }}$ lebih besar dari pada $\mathrm{t}_{\text {tabel }}(5,6>$ 2,09). Berdasarkan hasil konsultasi nilai tersebut maka hipotesis alternatif yang dirumuskan dalam penelitian ini dapat diterima atau disetujui kebenarannya. Hipotesis uji kenormalan Hasil belajar siswa tes awal (pretes) pada materi optik geometri adalah:

$\mathrm{Ha}=$ Hasil belajar mahasiswa tes awal (pre-tes) pada materi optik geometri berdistribusi normal

Ho = Hasil belajar mahasiswa tes awal (pretes) pada materi optik geometri tidak berdistribusi normal
Hipotesis uji kenormalan Hasil belajar mahasiswa tes akhir (post-tes) pada materi optik geometri adalah:

$\mathrm{Ha}=$ Hasil belajar mahasiswa tes akhir (posttes) pada materi optik geometri berdistribusi normal

Ho = Hasil belajar mahasiswa tes akhir (posttes) pada materi optik geometri tidak berdistribusi normal

Hasil penelitian tentang hasil belajar tes awal (Pre-tes) memperoleh rata-rata sebesar 68,86 dan simpangan baku sebesar 14,61. Jika $\chi^{2}$ hitung $>\chi$ tabel maka Ho ditolak.

Setelah dilakukan pembelajaran dengan menggunakan bahan ajar modul gelombang berbasis inkuiri pendekatan tersebut kedudukannya kuat. Hal ini, dapat dilihat dari hasil pre-tes 68,86 dan post-tes 76,45 
meningkat sebesar $7,59 \%$ yang menunjukkan bahwa terdapat peningkatan hasil belajar mahasiswa.

Berdasarkan uji hipotesis yang dilakukan peneliti bahwa penggunaan bahan ajar modul gelombang berbasis inkuiri sangat efektif terhadap hasil belajar optik geometri mahasiswa semster VI pendidikan fisika STKIP Tapanuli Selatan Padangsidimpuan. Hal ini dilihat dari nilai $t_{\text {hitung }}$ lebih besar dari nilai $t_{\text {tabel }}$ $(5,6>2,09)$.

\section{PEMBAHASAN}

Produk pengembangan bahan ajar modul gelombang berbasis inkuiri merupakan materi pembelajaran yang telah dikemabangkan dengan memperhatikan aspek pembelajaran. Penelitian pengembangan produk yang dilakukan ini diarahkan untuk menghasilkan suatu produk berupa bahan ajar modul gelombang berbasis inkuiri untuk mahasiswa pendidikan fisika STKIP Tapanuli Selatan Padangsidimpuan semester VI yang digunakan untuk meningkatkan proses pembelajaran maupun kompetensi mahasiswa. Oleh sebab itu proses penelitian dilakukan dan diawali dengan (1) studi pendahuluan, (2) mendesain media pembelajaran, (3) melakukan validasi produk dan melakukan revisi dan penyempurnaan berdasarkan analisis data validasi dari ahli media, (4) dilanjutkan dengan uji coba perorangan, uji coba kelompok kecil, dan uji coba lapangan sehingga dihasilkan bahan ajar modul gelombang berbasis inkuiri untuk mahasiswa pendidikan fisika STKIP Tapanuli selatan Padangsidimpuan yang layak digunakan yang sesuai dengan karakteristik bidang studi dan mahasiswa sebagi pengguna.

Aspek-aspekn yang direvisi dan disempurnakan berdasarkan analisis data dan uji coba serta masukan dari ahli materi, dan ahli media pembelajaran serta dosen dan mahasiswa selaku pengguna modul pembelajaran bertujuan untuk menggali beberapa aspek yang lazim dalam proses pengembangan suatu produk. Aspek-aspek bahan ajar modul gelombang berbasis inkuiri memiliki nilai rata-rata sangat baik.

Adapun manfaat yang diperoleh dalam menggunakan bahan ajar modul berbasis inkuiri adalah konsep yang disajikan secara sistematis dan sangat mudah untuk dipelajari dan dipahami. Bahan ajar modul gelombang berbasis inkuiri memberikan kesempatan kepada mahasiswa untuk belajar secara mandiri sesuai dengan karakternya masing-masing.

Dari hasil penelitian yang diperoleh pada pengembangan bahan ajar modul gelombang berbasis inkuiri untuk mahasiswa STKIP Tapanuli Selatan Padangsidimpuan merupakan penegmbangan media pembelajaran gelombang yang menerapkan prinsip-prinsip desain pembelajaran yang dilatar belakangi teori-teori yang berbeda yang disajikan dalam bentuk modul yang digunakan sebagai pedoman dalam penyelenggaraan pembelajaran agar tercapai pembelajaran yang efektif, efisien, berdaya guna, menarik dan humanis.

Penegmbangan bahan ajar modul gelombang berbasis inkuiri unutk mahasiswa pendidikan fisika STKIP Tapanuli Selatan sudah sesuai berdasarkan beberapa teori ahli bahan ajar yang dikemukakan oleh Supardi (2001:9) yang meliputi: mutu isi buku, kesesuaian dengan kurikulum, bahasa yang digunakan termasuk penyajian dan keterbacaannya, grafika, dan keamanan buku. Dan pengembangan bahan ajar modul gelombang berbasis inkuiri yang dihasilkan mengikuti prosedur-prosedur dalam pengembangan bahan ajar yang meliputi: (1) memahami standar isi dan standar kompetensi lulusan, silabus, program semeter, dan rencana pelaksanaan pembelajaran; (2) mengidentifikasi jenis materi pembelajaran berdasarkan pemahaman terhadap poin pertama; (3) melakuan pemetaan materi; (4) menetapkan bentuk penyajian; (5) menyusun struktur (kerangka) penyajian; (6) membaca buku sumber; (7) mendraf (memburam) bahan ajar; (8) merevisi (menyunting) bahan ajar; (9) mengujicobakan bahan ajar; dan (10) merevisi dan menulis akhir (finalisasi).

Berdasarkan teori pengembangan model Dick \& Carey (2005:9), pengembangan bahan ajar modul gelombang berbasis inkuiri untuk mahasiswa pendidikan fisika STKIP Tapanuli Selatan Padangsidimpuan ini adalah salah satu model pengembangan yang berorientasi pada hasil, karena penerapankonsep-konsep dan prinsip-prinsip perancangannya akan menghasilkan bahan belajar mandiri.

Dari hasil penelitian menunjukkan bahwa pengembangan bahan ajar modul gelombang berbasis inkuiri sangat sesuai dengan pengembangan model Dick \& Carey seperti yang ditunjukkan pada desain pengembangan pembelajaran dapat dilakukan dengan 
menggunakan tahap-tahap (1) Identifikasi tujuan pembelajaran; (2) Melakukan analisis pembelajaran; (3) Identifikasi perilaku dan karakteristik awal; (4) Menulis tujuan kerja; (5) Mengembangkan tes acuan patokan; (6) Mengembangkan strategi pembelajaran; (7) Mengembangkan dan memilih materi pembelajaran; (8) Mendesain dan melaksanakan evaluasi formatif; (9) Merevisi kegiatan pembelajaran; (10) Mendesain dan melaksanakan evaluasi sumatif.

\section{PENUTUP}

1. Hasil validasi dari para validator menunjukkan bahwa bahan ajar modul gelombang berbasis inkuiri yang dikembangkan valid dan layak untuk dipergunakan mahasiswa dalam pemebelajaran gelombang.

2. Bahan ajar modul gelombang berbasis inkuiri untuk mahasiswa pendidikan fisika efektif digunakan dalam pembelajaran gelombang. Ini dilihat dan adanya hasil belajar mahasiswa selama perkuliahan berlangsung.

\section{DAFTAR PUSTAKA}

Departemen Pendidikan Nasional. (2008). Panduan Pengembangan Bahan Ajar. Departemen Pendidikan Nasional. Direktorat Jenderal Manajemen Pendidikan Dasar dan Menengah, Direktorat Pembinaan Sekolah Menengah Atas.

Depdiknas. (2006). Model Penilaian Kelas Kurikulum Berbasis Kompetensi SMA /MA,Jakarta : BNSP Depdiknas.
Englewood Cliffs. Inc dalam Muslich, M. (2007). KTSP Pembelajaran Berbasis Kompetensi dan Kontekstual. Jakarta: Bumi Aksara

Mulyasa, E. (2010). Menjadi Guru Profesional. Bandung: PT. Remaja Rosdakarya.

Riduwan. (2011). Belajar Mudah Penelitian Untuk Guru, Karyawan dan Peneliti Pemula . Bandung:Alfabeta.

Setyosari. (1990). Pengajaran Modul. Malang: Proyek Operasi dan Perawatan Fasilitas IKIP Malang.

Sugiyono, (2008). "Metodologi Penelitian Pendidikan Pendekatan Kuantitatif, Kualitatif dan $R \& D$, Alfabeta, Bandung.

Sukmadinata, NS, (2005). Metode Penelitian Pendidikan. Jakarta: Program Pasca Sarjana UI dan PT Remaja Rosdakarya.

Sungkono, (2003). Pengembangan Bahan Ajar. Yogyakarta: FIP UNY.

Surapranata, S. (2009). Analisis, Valisitas, Reliabilitas dan Interpretasi Hasil Tes. Bandung: PT Remaja Rosdakarya offset.

Suryosubroto. (1983). Sistem Pengajaran dengan Modul. Yoyakarta: Bina Aksara.

Syarifuddin (2006) yang berjudul " Pengaruh pembelajaran inkuiri-kooperatif terhadap hasil belajar fisika siswa. Tesis S2 UNP Padang.

Tian Belawati, dkk. (2003). Pengembangan Bahan Ajar. Jakarta: Pusat Penerbitan UT.

Trianto. (2009). Mengembangkan Model pembelajaran Tematik. Jakarta: PT. Prestasi Pustaka

Vembrianto, ST. (1983). Pengantar Pengajaran Modul. Yogyakarta: Yayasan Pendidikan Paramita. 